\title{
Sound production in Sciaenops ocellatus: Preliminary study for the development of acoustic cues in aquaculture
}

\author{
Eric Parmentier ${ }^{a}$, Jérémy Tock $^{a}$, Jean-Claude Falguière ${ }^{b}$, Marylin Beauchaud $^{c, d}$
}

\author{
${ }^{a}$ Laboratoire de Morphologie Fonctionnelle et Evolutive, Institut de chimie, Bât. B6c, Université de Liège, B-4000 \\ Liège, Belgium \\ b Unité Biodiversité et Environnement, Délégation IFREMER des Antilles 79 Route de Pointe-Fort, 97231 Le \\ Robert, Martinique \\ ' Université de Lyon/Saint-Etienne, Equipe Neuro-Ethologie Sensorielle, ENES/CNPS, CNRS UMR 8195, 23, rue \\ Paul-Michelon, 42023 Saint-Etienne cedex 2, France \\ d Centre de Neurosciences Paris-Sud, CNRS UMR 8195, Orsay, France
}

\begin{abstract}
:
The red drum Sciaenops ocellatus is an estuarine-dependent sciaenid that has supported important recreational and commercial fisheries for many years. Since the 1980s, this species has been farmed in different regions of the world and studies have been conducted to find natural ways to improve its culture. Sciaenops ocellatus is well known for making calls but studies on this characteristic have been mainly restricted to passive acoustics. The aim of this study was to provide acoustic-related information that could be useful in rearing practices. We have studied in detail fish calling characteristics, described their sound-producing mechanism and tested the recordings in different kinds of confinements (floating cages, concrete and fibreglass tanks). Contrary to previous studies, calls were recorded mainly in the morning, between 06:00 and 09:00. Sounds are made only by males; females do not have sound-producing apparatus. The anatomy, muscle ultrastructure data and calling characteristics show conclusively that calls result from the contraction of high speed muscles which are characterized by the very small diameter $(7 \mu \mathrm{m})$ of the muscle cells. Preliminary results suggest sound characteristics can give information on the fish physiology but further studies are needed. The effects of resonance of fibreglass tanks are experimentally highlighted, showing unequivocally that all the characteristics of fish calls are completely distorted, even in big tanks $\left(13 \mathrm{~m}^{3}\right)$. These findings should be taken into account when using pre-recorded sounds in the rearing of this species because it can affect communication during courtship activity.
\end{abstract}

\section{Highlights}

Pioneer study on the use of acoustic data in aquaculture.

We can extract information from the fish calls that can help in aquaculture Advices concerning the pitfalls related to this kind of study Calls result from the contraction of high speed muscles $>$ Sound production only in males older than nine months

Keywords : acoustic ; red drum ; sonic ; muscle morphology 


\section{Introduction}

The teleosts of the family Sciaenidae are collectively known as the croakers and drums because of their propensity for making sounds (Fish, Mowbray, 1970; Ono, Poss, 1982). This ability has been known for centuries (Dufossé, 1874; Lagardère, Mariani, 2006; Rountree, Gilmore, Goudey, Hawkins, Luczkovich, Mann, 2006) and the association of sciaenid sounds with spawning has been known about for nearly as long (Darwin, 1874). Cuvier and Valenciennes noted, for example, that meagres can make louder sounds than gurnards and described them as muffled humming or sharp whistling that help fishermen to find the males (Cuvier, Valenciennes, 1830). Moreover, sciaenids are unique in the diversity of their sound production mechanisms and in the variety of sounds produced (Ramcharitar, Gannon, Popper, 2006). The mechanisms, however, follow roughly the same design: the swim bladder is dorsally surrounded by bilaterally symmetrical sonic muscles originating from the hypaxial musculature and inserting on a central tendon (Connaughton, Fine, Taylor, 1997; Hill, Fine, Musick, 1987; Ono, Poss, 1982; Tower, 1908). Sound production results from the fast contraction of sonic muscles, whose twitches drive the damped swim bladder in a transient response (Connaughton, Taylor, Fine, 2000; Sprague, 2000). This mechanism provides in this fish family trains of repeated pulses of sound, with each pulse decaying before the next pulse begins (Demski, Gerald, Popper, 1973; Fish, Mowbray, 1970; Guest, Lasswell, 1978; Lagardère, Mariani, 2006; Sprague, 2000; Tower, 1908). Fish producing sound in this manner generate fundamental frequencies between 100 and $>200 \mathrm{~Hz}$. This means that muscles are contracting at the same rate (Connaughton, 2004), placing them among the fastest vertebrate striated muscles. However, calling parameters may vary within sciaenid species depending on fish size, water temperature, geography and stage of the spawning season (Aalbers, Drawbridge, 2008; Chao, 1978; Connaughton, Taylor, Fine, 2000; Connaughton, Fine, Taylor, 1997; Ramcharitar, Gannon, Popper, 2006; Tellechea, Martinez, Fine, Norbis, 2010; Tellechea, Norbis, Olsson, Fine, 2011). Besides the swim bladder, another potential mechanism of sound production is stridulation of pharyngeal teeth (Burkenroad, 1931; Fish, Mowbray, 1970). However, production of sound by pharyngeal stridulation has not been demonstrated conclusively using experimental methods in any species of sciaenid and should be investigated further (Ramcharitar, Gannon, Popper, 2006).

Sciaenids produce at least two different types of calls (Ramcharitar, Gannon, Popper, 2006). Reproductive calling is most common during the spawning season and this behaviour often 
peaks during crepuscular or nocturnal hours (Connaughton, Taylor, 1995; Mok, Gilmore, 1983). Disturbance calls would indicate alarm, pain, annoyance or a similar state but additional studies are needed to understand these behaviours. However, not all of the sciaenid species are able to make different calls. The seatrout Cynoscion neubulosus, for example, is able to make four different types of sounds (Gilmore, 2003; Mok, Gilmore, 1983; Ramcharitar, Gannon, Popper, 2006; Sprague, Luczkovich, Pullinger, Johnson, Jenkins, Daniel, 2000), the meagre Argyrosomus regius produces two types (Lagardère, Mariani, 2006), while the weakfish Cynoscion regalis produces the same type of sound in different behavioural contexts (Connaughton, Lunn, Fine, Taylor, 2003).

Sound-producing ability is usually restricted to males (Connaughton, Taylor, 1995; 1996; Fish, Mowbray, 1970; Luczkovich, Sprague, Johnson, Pullinger, 1999). In some species, however, such as meagres (Argyrosomus regius and Argyrosomus argentatus), drum fish (Nibea albiflora), the Atlantic croaker Micropogon undulatus and the black drum Pogonias cromis, both males and females possess extrinsic sonic muscles and both sexes can produce sounds (Fish, Mowbray, 1970; Lagardère, Mariani, 2006; Takemura, Takita, Mizue, 1978).

The red drum Sciaenops ocellatus is an estuarine-dependent sciaenid that has supported important recreational and commercial fisheries for many years (Murphy, Taylor, 1990; Wilson, Nieland, 1994). Normally the spawning peak is in September or October, although spawning has been recorded in August and December as well (Davis, 1990; Holt, 2002).Since the 1980s, this species has been farmed in different regions and studies have been carried out to improve their rearing (Falguière, 2011; Parfouru, Fauvel, 1997). Although this species is known for its drumming sounds (Fish, Mowbray, 1970), paradoxically only very few studies have investigated this aspect of their biology. In tanks, during courtship activity, it was reported drumming began around dusk and the rate intensified significantly through the evening until spawning (Guest, Lasswell, 1978). The drumming call was made up of a burst of pulses with dominant energy in the $240-1,000 \mathrm{~Hz}$ range. Pulses were of $70-100 \mathrm{~ms}$ duration and calls were irregular in pulse repetition rate (pulses/s). The first two inter-pulse intervals were greater than others in a typical call (Guest, Lasswell, 1978). In the field, red drum sounds were also produced between 18:30 and 21:30. This was in the form of either a lowfrequency rumble with a prominent energy peak at approximately $150 \mathrm{~Hz}$ or a clearly distinguishable call made by individuals or small groups of red drum (Holt, 2008). Besides 
these few details, little is known about the sound characteristics, the mechanism used and whether both sexes are able to produce sounds.

Now that Sciaenops ocellatus is used in aquaculture (Falguière, 2011), information is required on all aspects of its biology to find elements that could help to improve its rearing. Acoustic behaviour should help for example to monitor the reproduction in captivity with the determination of the sexual status or maturity, the establishment of the spawning readiness, the distinction between males and females, etc. In relation to the density within tanks, it can also be used to evaluate the fish aggressiveness or wellness. The global aim is to provide acoustic-related information that could help fish farmers in the rearing of this species. We provide here: (1) more details on their calling and morphological characteristics and (2) some pitfalls future studies should avoid. Sounds were tentatively recorded in males and females at the end of the spawning period and outside the reproductive period.

\section{Material and methods}

The study took place in Martinique between February 5 and March 25. Fish were recorded in tanks and in floating cages placed in open sea.

1. Recordings of fish in floating cages $\left(30 \mathrm{~m}^{3}\right)$ were performed at three stations: in the Bay of Galion (Station 1: $14^{\circ} 42^{\prime} 51.17^{\prime \prime} \mathrm{N}-60^{\circ} 55^{\prime} 27.58^{\prime \prime} \mathrm{W}$ ) and in the Bay of Robert (Station 2:

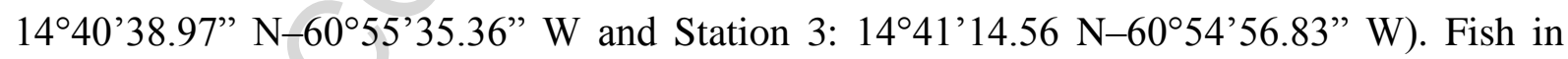
Station 1 were 2 years old (sexual maturation), >2 years old in Station 2 and 9 months old in Station 3.

2. Recordings in tanks were made at the Ifremer Station located in the Bay of Robert. Fish were recorded in three different types of tanks (temperature $26-29^{\circ} \mathrm{C}$ ): concrete tanks of 13 $\mathrm{m}^{3}$, fibreglass tanks of $13 \mathrm{~m}^{3}$ and fibreglass tanks of $6 \mathrm{~m}^{3}$.

\section{Recordings}

Recordings were made with two different devices in order to characterize their physical characteristics and to study the periodicity of call production.

1. Recordings of daily cycles were made with a Digital Spectrogram Recorder (DSG, Loggerhead Instruments Inc., Sarasota, FL). The DSG recorder is a long-term, low-power 
recorder of acoustic signals. The master sample rate was $40 \mathrm{kHz}$ and the hydrophone sensitivity was $-186 \mathrm{~dB}$ re. $1 \mathrm{~V} \mu \mathrm{Pa}^{-1}$. The system was scheduled to record for 10 min every 60 min. The DSG was first placed at a depth of $2 \mathrm{~m}$ for 7 days in open sea, close to $30 \mathrm{~m}^{3}$ floating cages $(4 \times 3 \times 2.5 \mathrm{~m})$ in the vicinity of Station 2 . The main cage is divided in nine cages containing 30-90 fish of 3-5 years old and weighing between 1 to 2,800 $\mathrm{kg}$. Males in these cages were still spermatic but it was at the end of the reproductive period. In addition, the DSG was placed for 3 days at Station 3 and 4 days at Station 1. As well as making recordings in open sea, the DSG was also placed for 3 days in a fibreglass tank $\left(13 \mathrm{~m}^{3}\right)$ containing 20 specimens of 5-9 years old (2-6 kg) and out of the spawning period. The different sexual status is due to the fact that fish of the second lot are in a shifted period tank. This permits two spawning periods during the year. Recordings in the field were realized without any manipulation of the fish. In each case, sounds were digitized at $22 \mathrm{kHz}$ (16-bit resolution), low-pass filtered at $2 \mathrm{kHz}$ and analysed using AvisSoft-SAS Lab Pro 4.33 software. Sounds were counted and the number of pulses/sound was noted.

2. Sounds were also recorded with a hydrophone HTI (sensitivity $164 \mathrm{~dB}$ re. $1 \mathrm{~V} \mu \mathrm{Pa}^{-1}$ ) connected to a Tascam DR-05 recorder. In tanks, prior to the recording sessions, all electric devices (ventilation, pumps and heating system) were unplugged and the hydrophone was positioned at the centre of the tanks. Sounds were digitized at $44.1 \mathrm{kHz}$ (16-bit resolution), low-pass filtered at $2 \mathrm{kHz}$ and analysed using AvisSoft-SAS Lab Pro 4.33 software.

Sounds were recorded in different contexts. (1) The first set of data collection was done without any manipulation of the fish. These recordings were made in tanks containing both males and females or only males or only females. (2) Sounds were also recorded during the emptying of the tanks to induce fish stress.

\section{Sound analysis}

Only the sounds with a good signal-to-noise ratio were used in the analysis. Temporal features were measured from oscillograms and frequency parameters were obtained from power spectra. The following sound parameters were measured: sound duration (ms); number of pulses in a sound; pulse period (measured as the average peak-to-peak interval between consecutive pulses in the entire sound, in ms); pulse length (measured as the time from the beginning of one pulse to its end) and dominant frequency $(\mathrm{Hz})$.

\section{Muscle anatomy}


Six males (6-9 years old) and three females (5-8 years old) were killed with MS-222 (500 mg $\left.1^{-1}\right)$ to localize sound-producing muscles and describe the gross anatomy of the sonic mechanism. Samples of these muscles and of white epaxial muscles were fixed for $48 \mathrm{~h}$ in $2.5 \%$ glutaraldehyde for observation by transmission electron microscopy (TEM). After glutaraldehyde fixation, muscle samples were dehydrated in an ethanol-propylene oxide series and embedded in epoxy resin (SPIPON 812). First, morphology was observed in 6-7 $\mu \mathrm{m}$ sections stained with toluidine blue. The cellular ultrastructure was then examined on ultrathin sections stained with uranyl acetate and lead citrate. The sections were viewed with a JEOL JEM 100SX TEM under an $80 \mathrm{kV}$ accelerating voltage.

\section{Statistical analysis}

Statistical analyses were performed with STATISTICA 10 and Graphpad Prism 5 (Graphpad Software, Inc.). The latter was also employed for graphical illustration. In addition to elementary statistics, the normality of data was tested with the Shapiro-Wilk test to determine whether parametric tests were appropriate. Variables that did not violate assumptions of normality were compared with a Student's t-test, while variables with a non-normal distribution were tested with a Mann-Whitney U test. Comparisons of acoustic characteristics between the different tanks were tested with the Kruskal-Wallis test.

\section{Results}

Sounds were recorded at the end of the spawning period (when males were still spermatic but there was no courtship activity) but not outside the reproduction period. Calls were made in different conditions: (1) males and females in the same tank, (2) only males $(n=6)$ in a single tank, (3) pairs of males placed in the same tank and (4) only one male in the tank. However, no sounds were obtained from females isolated in a single tank or from specimens of 9 months old. We conclude that only males are able to produce sounds and, consequently, that calls recorded in the floating cages were made by males. Besides the sounds in the field, calls were also recorded during the emptying of the tank. It was, however, not possible to analyse these sounds because the water volume was gradually decreasing, modifying the tank resonance and most of the time masking the sounds. Moreover, in this stressful situation fish swam more rapidly along the tank walls, which increased the background noise. In these conditions, it was only possible to count the number of pulses per call. This shows at least that stress conditions can also induce sound production in this species. 


\section{Daily rhythms}

In the floating cage (Station 2) with 31 specimens, the daily sound production of males (3-5 years old, 1-7.7 kg) at the end of the spawning period (but still spermatic) was estimated at between 2,118 and 4,554 sounds/day. Sounds were produced throughout the day but the production was not uniform. Chorus activity began to increase after midnight and peaked from 06:00 to 09:00. Call numbers then diminished regularly before an increase to a smaller second peak at noon. The sound production then decreased regularly untill18:00 and very few sounds were recorded after sunset and overnight. This activity pattern was observed each day (Fig. 1).

Males (10 specimens, 5-8 years old, 2-6.4 kg) in a shifted period tank (i.e. outside the reproduction period) only made 156 sounds/day. This allows the hypothesis of relationships between courtship and sonic activities.

At the end of the spawning period, trains of calls recorded at Stations 1 and 2 comprised between one and seven pulses $(n=400$ calls), with most sounds having three or four pulses. The sound duration was positively related to the number of pulses $\left(R^{2}=0.9478, y=0.0979 x\right.$ -0.0112 ), highlighting the constant rate of pulse production.

Analysis of sound characteristics was conducted on sounds recorded in floating cages. Data were collected on calls having three or four pulses. Each pulse had three high-amplitude halfcycles sometimes followed by decaying lower amplitude oscillations (Fig. 2). Most energy occurred in the first cycle, and the amplitude of the second cycle decayed by about half. Pulses lasted between 9 and $42 \mathrm{~ms}$ (mean \pm S.D. $=23 \pm 4 \mathrm{~ms}, \mathrm{n}=700$ sounds from 33 specimens) and we did not observe significant differences in the pulse duration due to its position in the call (Shapiro-Wilk, $\mathrm{H}=0.33 ; \mathrm{p}=0.95$ ). The first period (time between the first and second pulse) was significantly longer $(151 \pm 18 \mathrm{~ms}, \mathrm{n}=200)$ than other periods $(140 \pm$ $14 \mathrm{~ms}, \mathrm{n}=200$ for the second period and $142 \pm 16 \mathrm{~ms}, \mathrm{n}=100$ for the third period). The sound spectrum of a pulse contained energy with a wide bandwidth, between 50 and $750 \mathrm{~Hz}$. The dominant frequency ranged from 78 to $157 \mathrm{~Hz}(105 \pm 32 \mathrm{~Hz}, \mathrm{n}=200)$ and did not show harmonics (Fig. 2). 


\section{Comparison of the confinements}

Sound features (Table 1) were compared between sounds recorded in floating cages, concrete tanks $\left(13 \mathrm{~m}^{3}\right)$ and fibreglass tanks $\left(13 \mathrm{~m}^{3}\right.$ and $\left.6 \mathrm{~m}^{3}\right)$. Analyses were restricted to sounds having three pulses to minimize bias as much as possible. All the sound features (sound duration, pulse duration, pulse period and dominant frequency) recorded in fibreglass tanks $\left(13 \mathrm{~m}^{3}\right.$ and $\left.6 \mathrm{~m}^{3}\right)$ were significantly higher than sounds from fish in floating cages (Table 2). Concrete tanks only differed significantly from open sea with respect to sound duration. They were no significant differences between results from the two sizes of fibreglass tank. Concrete tank features were all significantly different from fibreglass tank characteristics, except at with respect to sound duration, which did not differ between concrete tanks and fibreglass tanks $\left(13 \mathrm{~m}^{3}\right.$ ). The comparative oscillograms (Figure 3) show clearly the differences in: the decay is much longer in the fibreglass tank due to resonating effects, clearly indicating that pulses and calls are modified in tanks.

\section{Morphology}

The swim bladder shape and size are the same in males and females. The swim bladder has an oblique orientation, is large and occupies the entire length of the abdominal cavity (Fig. 4). It is firmly attached to the vertebral column at its anterior end and tapers posteriorly, at the level of the anal fin. Sonic muscles were found in males but not in females. These muscles cover the dorsaltwo-thirds of the posterior part of the swim bladder (Fig. 4), consisting of bilaterally symmetrical muscles that are perpendicular to the fish axis. These muscles originate from the abdominal hypaxial musculature and insert on a central tendon that lies dorsal to the swim bladder. This muscle could be considered as being digastric. Sonic muscles are deep red and covered by large amount of fat tissue.

\section{Histology}

Cross-sections of sonic muscles and tendons revealed undulations that could be the result of the presence of elastic fibres. From a functional point of view, this means that the resting muscle is stretched in situ. This arrangement should increase muscle contraction because elastic fibres should favour the speed of fibre shortening. The diameters of sonic fibres are extremely small, from 5 to $12.5 \mu \mathrm{m}$ (mean \pm S.D., $7.6 \pm 2.3 \mu \mathrm{m}, \mathrm{n}=50$ ). For comparison, the diameters of epaxial muscle fibres ranged from 37.5 to $105 \mu \mathrm{m}$. This means that these fibres 
are 21 times larger than sonic fibres (Fig. 4). These fibres are covered by numerous blood vessels and capillaries (Fig. 4).

\section{TEM}

This part of study was made with spermatic males but outside the spawning event, after reproduction. Small muscle cells consist mainly of ribbon-like blocks of myofibrils completely surrounded by mitochondria (Fig. 5). Some cells also show a central core of mitochondria. Triads are found at the level of the $\mathrm{Z}$ line. The spacing between triads is between 1.5 and $2.2 \mu \mathrm{m}$ in epaxial muscle and significantly smaller in sonic muscle, between 0.25 and $0.625 \mu \mathrm{m}$. Mitochondria are proportionally more numerous in sonic muscle: they are mainly found at the periphery but in some fibres can also occupy the central core of the muscle. Both types of cell also have differences with respect to the sarcoplasm, which is more developed at the periphery in sonic muscle than in epaxial muscle (Fig. 5).

\section{Discussion}

We have clearly demonstrated that sound production occurs only in males since no sounds were recorded in tanks containing only females, nor did we find any sound-producing muscles in females. In 9-month-old males, sonic muscles are present but they are apparently not functional because no sound was recorded in this group. This indicates that muscle development takes place before testicular maturity, which occurs at around 2 years old in this species (Murphy, Taylor, 1990). The same observations have also been reported in

Micropogonias undulatus and Leiostomus xanthurus (Hill, Fine, Musick, 1987). This area merits further study because sounds in younger specimens could be used to predict sexual maturity. In Cynoscion guatucupa, for example, the relationship between dominant frequency and total length is not linear and the modification in the regression slope seems to correspond to sexual maturity (Tellechea, Norbis, 2012).

Data recorded during spawning activity (Guest, Lasswell, 1978; Holt, 2002) and from unpublished results (Beauchaud, pers. com.) indicate that the number of pulses/sound would be more higher (up to nine on average) during spawning activity than outside (three to four in this study). This shows that the rate of acoustic activity of Sciaenops ocellatus can be related to the spawning period (Lagardère, Mariani, 2006; Locascio, Mann, 2011; Locascio, Burghart, Mann, 2012; Ramcharitar, Gannon, Popper, 2006; Tellechea, Norbis, 2012; Tower, 
1908; Veerappan, Pandi, Balasubramanian, 2009). Further studies should be conducted in $S$. ocellatus to relate the calling rate to the spawning season; we should be able to create a model indicating which part of the spawning cycle the fish have reached on the basis of at least the amount of pulses/calls. However, calls were also detected in the non-reproductive season, showing that they are not just restricted to reproduction. Fish were also able to produce distress calls when subjected to disturbance stimuli. In contrast to the striped weakfish Cynoscion guatucupa (Tellechea, Norbis, 2012), we were not able to find features allowing a clear distinction between advertisement calls and disturbance calls.

Although there is a clear relationship between male maturity and calling abilities, there is a discrepancy between the daily activity we recorded and the literature. In both tanks and field studies, most of the acoustic activity in S. ocellatus has been reported as occurring mainly at the end of the day, from 19:00 to 22:40 (Guest, Lasswell, 1978; Holt, 2002), and as corresponding to spawning events (Falguière, 2011; Holt, Holt, Arnold, 1985; Holt, 2008). This relationship between sound production and reproduction has also been highlighted in other sciaenids (Lagardère, Mariani, 2006; Locascio, Mann, 2011; Locascio, Burghart, Mann, 2012; Ramcharitar, Gannon, Popper, 2006; Tower, 1908; Veerappan, Pandi, Balasubramanian, 2009). In different sciaenid species, calls have been shown to serve in the formation of spawning aggregations, rallying individuals to the same spawning site (Gilmore, 2003; Mok, Gilmore, 1983). We did not observe reproduction during our recordings but our results indicate that the highest rate of activity took place between 06:00 and 09:00 and not at dusk as it is usually the case during the spawning period. Additional information could explain this paradox: males were still spermatic and sounds were recorded after the spawning period. As is the case in many sciaenids, sonic activity is used to aggregate the fish during the morning and the afternoon. However, after the spawning period the conditions required for courtship behaviour are no longer needed. This results in no sound production and no courtship at night, showing that passive acoustic sounds could be used in aquaculture to monitor the male physiological state.

As in most sciaenids, sonic muscles originate from the abdominal hypaxial musculature and insert on a central tendon that lies dorsal to the swim bladder (Hill, Fine, Musick, 1987; Ono, Poss, 1982; Ramcharitar, Gannon, Popper, 2006; Tower, 1908). The anatomy, muscle ultrastructure data and calling characteristics show conclusively that calls result from the contraction of high speed muscles. Fibres in the sound-producing muscles in S. ocellatus have 
all the known morphological convergent adaptations for speed (Bass, Marchaterre, 1989; Fawcett, Revel, 1961; Fine, Bernard, Harris, 1993; Loesser, Rafi, Fine, 1997). They have an unusual radial morphology in which the contractile cylinder comprises alternating ribbons of sarcoplasmic reticulum (SR) and myofibrils (Fine, Bernard, Harris, 1993; Ladich, 2001). The space at the periphery and the presence of a central core show they have an increased space devoted to the sarcoplasmic reticulum, sarcoplasm and mitochondria, all of which reduce the space available for the force-generating myofilaments (Appelt, Shen, Franzini-Armstrong, 1991; Bass, Marchaterre, 1989; Schaeffer, Conley, Lindstedt, 1996). Sound-producing muscles are also quite exceptional in terms of their size: muscle cell sections have extremely thin diameter $(7.6 \mu \mathrm{m})$ in comparison to high speed muscles of other species, where the average diameter varies between 11 and $40 \mu \mathrm{m}$ (Parmentier, Diogo, 2006). Finally, their elastic properties should help the muscle contraction.

Drumming sounds produced by many members of the Sciaenidae family are examples of pulsed sounds. In this case, a single pulse corresponds to a unit of muscle activity (Tower, 1908). This mechanism of sound generation has already been described in the weakfish Cynoscion regalis (Connaughton, Fine, Taylor, 2002), in the meagre Argyrosomus regius (Lagardère, Mariani, 2006), and was modelled by Sprague (2000) as the "single sonic muscle twitch model". In these fish, each pulse is produced by an individual twitch of sonic muscle causing multiple swim bladder oscillations that radiate sound into the surrounding water (Sprague, 2000). Four common features in the sounds of the weakfish, the meagre and the red drum lead us to believe that the mechanism is the same in all three fish species: the acoustic waveform of pulses decays rapidly, the short pulses of sound are separated by intervals of no sound (Sprague, 2000), the sound spectrum of an individual pulse contains energy with a wide bandwidth (Connaughton, Fine, Taylor, 2002; Fine, Malloy, King, Mitchell, Cameron, 2001) and, despite the large variations in fish size, the variability of the dominant frequency is low (Parmentier, Vandewalle, Brie, Dinraths, Lecchini, 2011). The acoustic waveform would correspond to the contraction and relaxation components of the sound (Fine, Malloy, King, Mitchell, Cameron, 2001). In red drum, each muscle twitch is assumed to produce individual pulses with the cycle of each pulse giving the dominant frequency of the sound (Lagardère, Mariani, 2006).

\section{Tank effect}


The effects of reverberation, resonance and tank size on the characteristics of sounds recorded inside small glass tanks have already been addressed because these factors are known to influence the recordings (Akamatsu, Okumura, Novarini, Yan, 2002). In their important study, Akamatsu and his colleagues showed the pitfalls associated with recording fish sounds in small tanks: dominant frequency, sound-pressure level and power spectrum recorded in small tanks (37 1 and 1,800 1) were all significantly distorted compared to the original tone bursts. Comparison of the calls recorded at sea and sounds recorded in tanks clearly confirm these results (all the sound characteristics are affected) and show clearly that distortions also occur in fibreglass tanks $\left(6 \mathrm{~m}^{3}\right.$ and $\left.13 \mathrm{~m}^{3}\right)$. In addition to the study of Akamatsu et al. (Akamatsu, Okumura, Novarini, Yan, 2002), we have shown that the pulse period can also be affected by fibreglass tanks. All these findings should be taken into account when using sounds in the rearing of this species as they show that during the spawning period females receive only distorted cues from the calling males in rearing conditions.

\section{Acknowledgement}

The authors are grateful to the team at the Unité Biodiversité et Environnement de La Martinique, especially S. Devillers and L. Faure for providing access to facilities, and helping in fish recording and dissections. The fish farmers P. Verdan and P. Villanove both kindly agreed to us using their floating cages for our recordings. N. Decloux efficiently helped in the microscopic study. This is the AFFISH-RC (Applied and Fish Research Center) publication no. XX.

\section{References}

Aalbers, S.A., Drawbridge, M.A., 2008. White seabass spawning behavior and sound production. Trans Am Fish Soc. 137, 542-550.

Akamatsu, T., Okumura, T., Novarini, N., Yan, H.Y., 2002. Empirical refinements applicable to the recording of fish sounds in small tanks. J Acoust Soc Am. 112, 3073-3082.

Appelt, D., Shen, V., Franzini-Armstrong, C., 1991. Quantitation of Ca ATPase, feet and mitochondria in super fast muscle fibers from the toadfish, Opsanus tau. J Muscle Res Cell Motil. 12, 543552.

Bass, A.H., Marchaterre, M.A., 1989. Sound-generating (sonic) motor system in a teleost fish (Porichthys notatus): Sexual polymorphisms and general synaptology of sonic motor nucleus. J Comp Neurol. 286, 154-169.

Burkenroad, M.D., 1931. Notes on the sound-producing marine fishes of Louisiana. Copeia. 1, 20-28.

Chao, L.N., 1978. A basis for classifying western Atlantic Sciaenidae (Teleostei: Perciformes). NOAA Technical Report NMFS Circular. 415, 1-64. 
Connaughton, M., Taylor, M., Fine, M., 2000. Effects of fish size and temperature on weakfish disturbance calls: implications for the mechanism of sound generation. J Exp Biol. 203, 1503 1512.

Connaughton, M., Fine, M., Taylor, M., 2002. Review. Weakfish sonic muscle: influence of size, temperature and season. J Exp Biol. 205, 2183 - 2188.

Connaughton, M.A., 2004. Sound generation in the searobin (Prionotus carolinus), a fish with alternate sonic muscle contraction. J Exp Biol. 207, 1643-1654.

Connaughton, M.A., Taylor, M.H., 1995. Seasonal and daily cycles in sound production associated with spawning in weakfish, Cynoscion regalis. Environ Biol Fishes. 42, 233-240.

Connaughton, M.A., Taylor, M.H., 1996. Drumming, courtship, and spawning behavior in captive weakfish, Cynoscion regalis. Copeia. 1996, 195-199.

Connaughton, M.A., Fine, M.L., Taylor, M.H., 1997. The effect of seasonal hypertrophy and atrophy of fiber morphology, metabolic substrate concetration and sound characteristics of the weakfish sonic muscle. J Exp Biol. 200, 2449-2457.

Connaughton, M.A., Lunn, M.L., Fine, M.L., Taylor, M.H., 2003. Characterization of sounds and their use in two sciaenid species: weakfish and Atlantic croaker. in: Rountree, R.A., Goudey, C., Hawkins, T. (Eds.), Listening to fish: passive acoustic applications in marine fisheries. Massachusetts Institute of Technology, Sea Grant College Program, Cambridge, Massachusetts, pp. 15-19.

Cuvier, G., Valenciennes, A., 1830. Histoire Naturelle des poissons, Tome V. F.G. Levrault, Strasbourg.

Darwin, C., 1874. The descent of man. 2nd edition. H. H. Caldwell, New York.

Davis, J.T., 1990. Red drum: Biology and life history. SRAC publication. 320, 1-2.

Demski, L.S., Gerald, J.W., Popper, A.N., 1973. Central and Peripheral Mechanisms of Teleost Sound Production. Am Zool. 13, 1141-1167.

Dufossé, L., 1874. Recherches sur les bruits et les sons expressifs que font entendre les poissons d' Europe et sur les organes producteurs de ces phénomènes acoustiques, ainsi que sur les appareils de l'audition de plusieurs de ces animaux. Annales des Sciences Naturelles, 5th série. 20, 117.

Falguière, J.C., 2011. L'ombrine ocellée, Sciaenops ocellatus. Edition Quae, Versailles.

Fawcett, D.W., Revel, J.P., 1961. The sarcoplasmic reticulum of a fast-acting fish muscle. J Biophys Biochem Cytol. 10, 89-109.

Fine, M.L., Bernard, B., Harris, T.M., 1993. Functional morphology of toadfish sonic muscle fibers: relationship to possible fiber division. Can J Zool. 71, 2262-2274.

Fine, M.L., Malloy, K.L., King, C.B., Mitchell, S.L., Cameron, T.M., 2001. Movement and soung generation by toadfish swimbladder. J Comp Physiol A. 187, 371-379.

Fish, M.P., Mowbray, H.M., 1970. Sounds of Western North Atlantic Fishes. The Johns Hopkins Press, Baltimore.

Gilmore, R.G., 2003. Sound production and communication in the spotted seatrout. in: Bortone, S.A. (Ed.), Biology of the spotted seatrout. CRC Press, Boca Raton, Florida, pp. 177-195.

Guest, W.C., Lasswell, J.L., 1978. A note on courtship behavior and sound production of red drum. Copeia. 2, 337-338.

Hill, G., Fine, M., Musick, J., 1987. Ontogeny of the sexually dimorphic sonic muscle in three sciaenid species. Copeia. 3, 708-713.

Holt, G.J., Holt, S.A., Arnold, C.R., 1985. Diel periodicity of spawning in Sciaenids. Mar Ecol Prog Ser. 27, 1-7.

Holt, S.A., 2002. Intra- and inter-day variability in sound production by red drum (Sciaenidae) at a spawning site. Bioacoustics. 12, 227-229.

Holt, S.A., 2008. Distribution of red drum spawning sites identified by a towed hydrophone array. Trans Am Fish Soc. 137, 551-561.

Ladich, F., 2001. Sound-generating and -detecting motor system in catfish: design of swimbladder muscles in doradids and pimelodids. Anat Rec. 263, 297-306. 
Lagardère, J.P., Mariani, A., 2006. Spawning sounds in meagre Argyrosomus regius recorded in the Gironde estuary, France. J Fish Biol. 69, 1697-1708.

Locascio, J.V., Mann, D.A., 2011. Diel and seasonal timing of sound production by black drum (Pogonias cromis). Fish Bull. 109, 327-338.

Locascio, J.V., Burghart, S., Mann, D.A., 2012. Quantitative and temporal relationships of egg production and sound production by black drum Pogonias cromis. J Fish Biol. 81, 1175-1191.

Loesser, K.E., Rafi, J., Fine, M.L., 1997. Embryonic, juvenile, and adult development of the toadfish sonic muscle. Anat Rec. 249, 469-477.

Luczkovich, J.J., Sprague, M.W., Johnson, S.E., Pullinger, R.C., 1999. Delimiting spawning areas of weakfish, Cynoscion regalis (family Sciaenidae) in Pamlico Sound, North Carolina using passive hydroacoustic surveys. Bioacoustics. 10, 143-160.

Mok, H.K., Gilmore, R.G., 1983. Analysis of sound production in estuarine fish aggregations of Pogoniascromis, Bairdiella chrysoura, and Cynoscion neubulosus (Sciaenidae). Bull Inst Zool Acad Sin. 22, 157-186.

Murphy, M.D., Taylor, R.G., 1990. Reproduction, growth, and mortality of red drum Sciaenops ocellatus in Florida waters. Fish Bull. 88, 531-542.

Ono, R.D., Poss, S.G., 1982. Structure and innervations of the swimbladder musculature in the weakfish, Cynoscion regalis (Teleostei: Sciaenidae). Can J Zool. 60, 1955-1967.

Parfouru, D., Fauvel, C., 1997. Dévelopement ovocytaire chez l'ombrine, Sciaenops ocellatus, en conditions tropicales Martiniquaises. Proc Gulf Caribb Fish Inst. 50, 551-573.

Parmentier, E., Diogo, R., 2006. Evolutionary trends of swimbladder sound mechanisms in some teleost fishes. in: Ladich F, Collin SP, Moller P, BG, K. (Eds.), Communication in Fishes. Science Publishers, Enfield, NH, pp. $45-70$.

Parmentier, E., Vandewalle, P., Brie, C., Dinraths, L., Lecchini, D., 2011. Comparative study on sound production in different Holocentridae species. Front Zool. 8, 12.

Ramcharitar, J., Gannon, D., Popper, A., 2006. Bioacoustics of fishes of the family Scianidae (croackers and drums). Trans Am Fish Soc. 135, 1409 - 1431.

Rountree, R.A., Gilmore, R.G., Goudey, C.A., Hawkins, A.D., Luczkovich, J.J., Mann, D.A., 2006. Listening to fish: applications of passive acoustics to fisheries science. Fisheries 31, 433-446.

Schaeffer, P., Conley, K., Lindstedt, S., 1996. Structural correlates of speed and endurance in skeletal muscle: the rattlesnake tailshaker muscle. J Exp Biol. 199, 351-358.

Sprague, M.W., 2000. The single sonic muscle twitch model for the sound-production mechanism in the weakfish, Cynoscion regalis. J Acoust Soc Am. 108, 2430-2437.

Sprague, M.W., Luczkovich, J.J., Pullinger, R.C., Johnson, S.E., Jenkins, T., Daniel, H.J., 2000. Using spectral analysis to identify drumming sounds of some North Carolina fishes in the family Sciaenidae. J Elisha Mitchell Sci Soc. 116, 124-145.

Takemura, A., Takita, T., Mizue, K., 1978. Studies on the underwater sound - VII. Underwater calls of the Japanese marine drum fishes (Sciaenidae). Bull Jpn Soc Fish Oceanogr. 44, 121-125.

Tellechea, J.S., Norbis, W., 2012. Sexual dimorphism in sound production and call characteristics in the striped weakfish Cynoscion guatucupa. Zool Stud. 51, 946-955.

Tellechea, J.S., Martinez, C., Fine, M.L., Norbis, W., 2010. Sound production in the whitemouth croaker and relationship between fish size and disturbance call characteristics. Environ Biol Fishes. 89, 163-172.

Tellechea, J.S., Norbis, W., Olsson, D., Fine, M.L., 2011. Calls of the black drum (Pogonias cromis: Sciaenidae): geographical differences in sound production between northern and southern hemisphere populations. Journal of Experimental Zoology Part A: Ecological Genetics and Physiology. 315A, 48-55.

Tower, R.W., 1908. The production of sound in the drumfishes, the searobin and the toadfish. Ann N Y Acad Sci. 18, 149-180.

Veerappan, N., Pandi, V., Balasubramanian, T., 2009. Sound production behaviour in a marine croaker fish, Kathala axillaris (Cuvier). World Journal of Fish and Marine Sciences, 206-211. 
Wilson, C.A., Nieland, D.L., 1994. Reproductive biology of red drum, Sciaenaps ocellatus, from the neritic waters of the northern Gulf of Mexico. Fish Bull. 92, 841-850.

Figure 1. Calling activity ( $\mathrm{N}=7$ days) of Sciaenops ocellatus $(\mathrm{n}=31)$ in floating cages. Sunrise: 06:05; sunset: 18:15.

Figure 2. Characteristics of the calls produced by Sciaenops ocellatus. A: oscillogram of a train made of four pulses. B: Power spectrum of a single pulse (upper line). The grey zone corresponds to the recorded ambient noise before or after sound emissions. (1): Call duration; (2): pulse period; (3) pulse duration.

Figure 3. Oscillogram of pulses recorded in A: floating cage; B: $13 \mathrm{~m}^{3}$ concrete tank; C: 13 $\mathrm{m}^{3}$ fibreglass tank; D: $6 \mathrm{~m}^{3}$ fibreglass tank. 
Figure 4. Characteristics of the sound-producing apparatus in Sciaenops ocellatus. In the fish in left lateral view, the blue line corresponds to the shape of the swim bladder and the red lines to the position of the sonic muscle. In the schematic cross-section, left and right sonic muscles are dorsally united by the aponeurosis. A to D: semi-thin sections of the epaxial (AC) and sonic (B-D) muscles. A and B: cross-sections; C and D: longitudinal sections. bv: blood vessel. Note the small sizes of the muscle cells in cross-sections (B) and that the elasticity of the sonic muscle gives an undulating shape to the longitudinal section (D). Scale bar: $0.1 \mathrm{~mm}$.

Figure 5. Transverse $(A: \times 8,000)$ and longitudinal sections $(B: \times 8,000$ and $C: \times 15,000)$ of the sonic muscle in Sciaenops ocellatus. M: M line; Mt: mitochondria; My: myofibril; RS: reticulum sarcoplasmic; Sa: sarcomere; Sc: sarcolemma; Tr: triad; Z: Z line. 


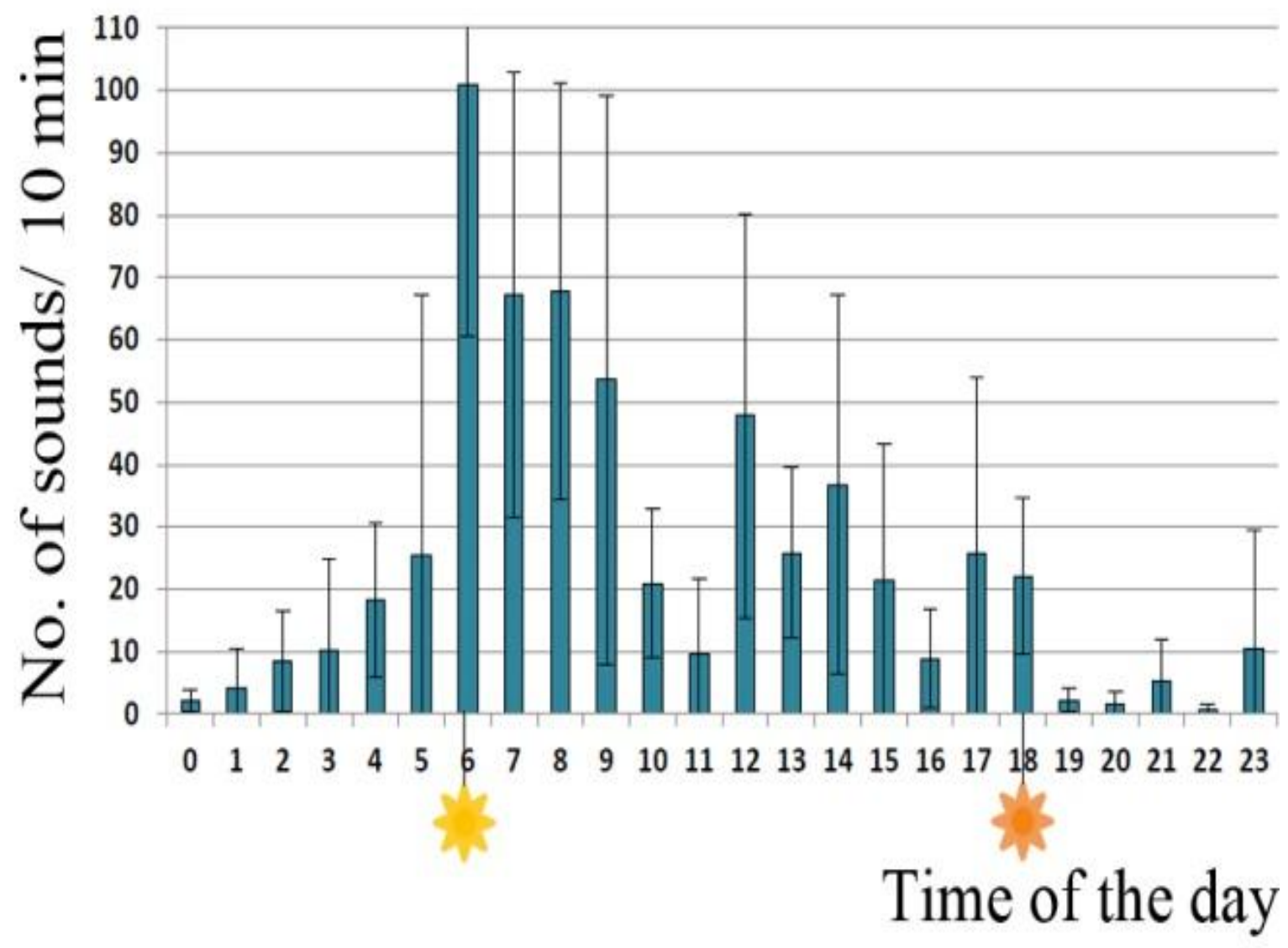

Figure 1 

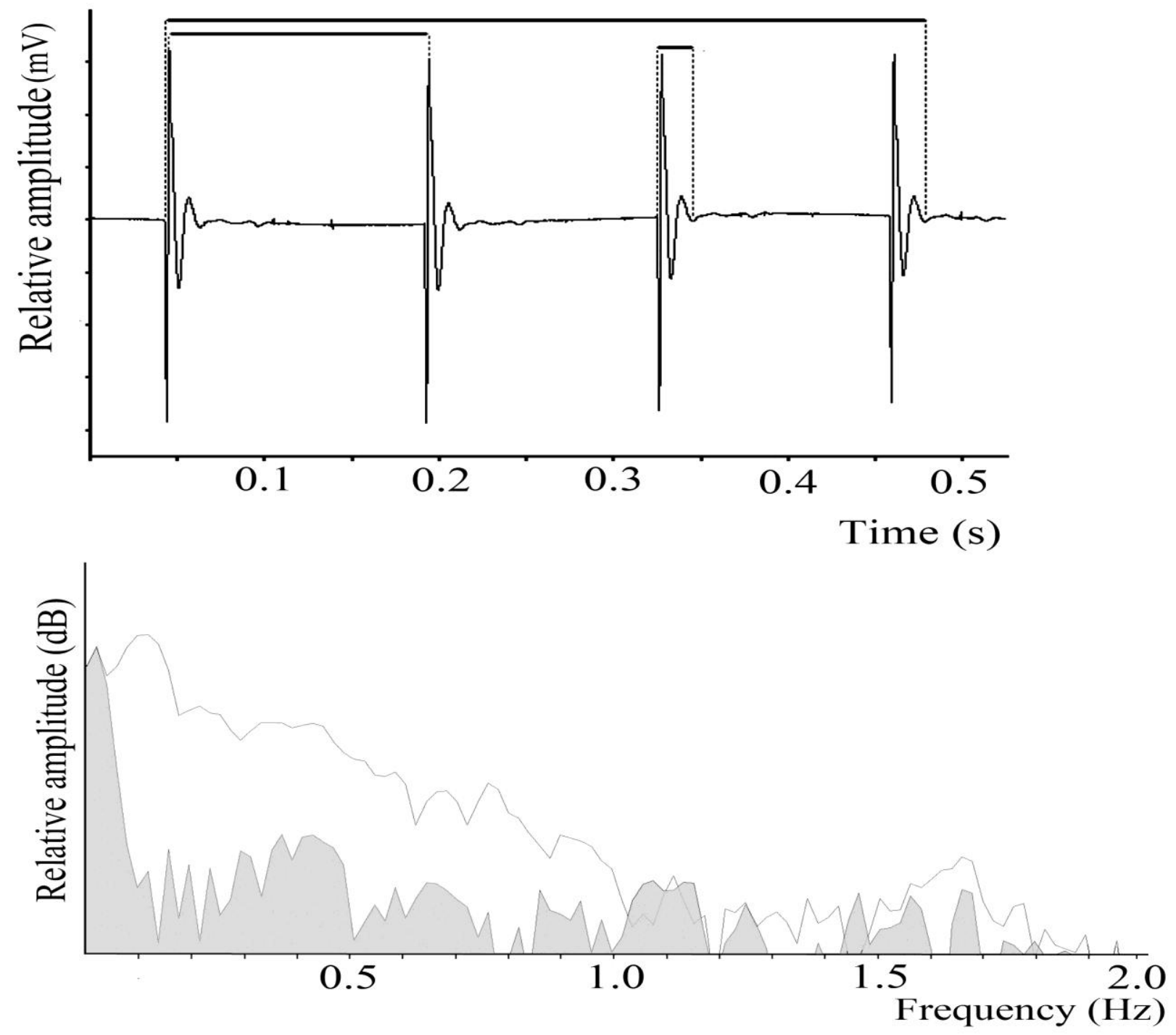

Figure 2 


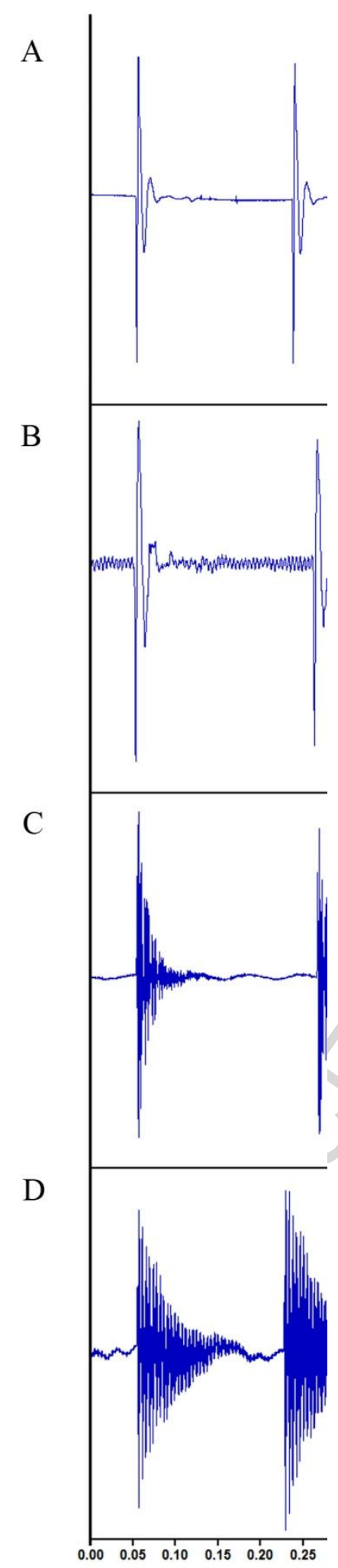

Figure 3 

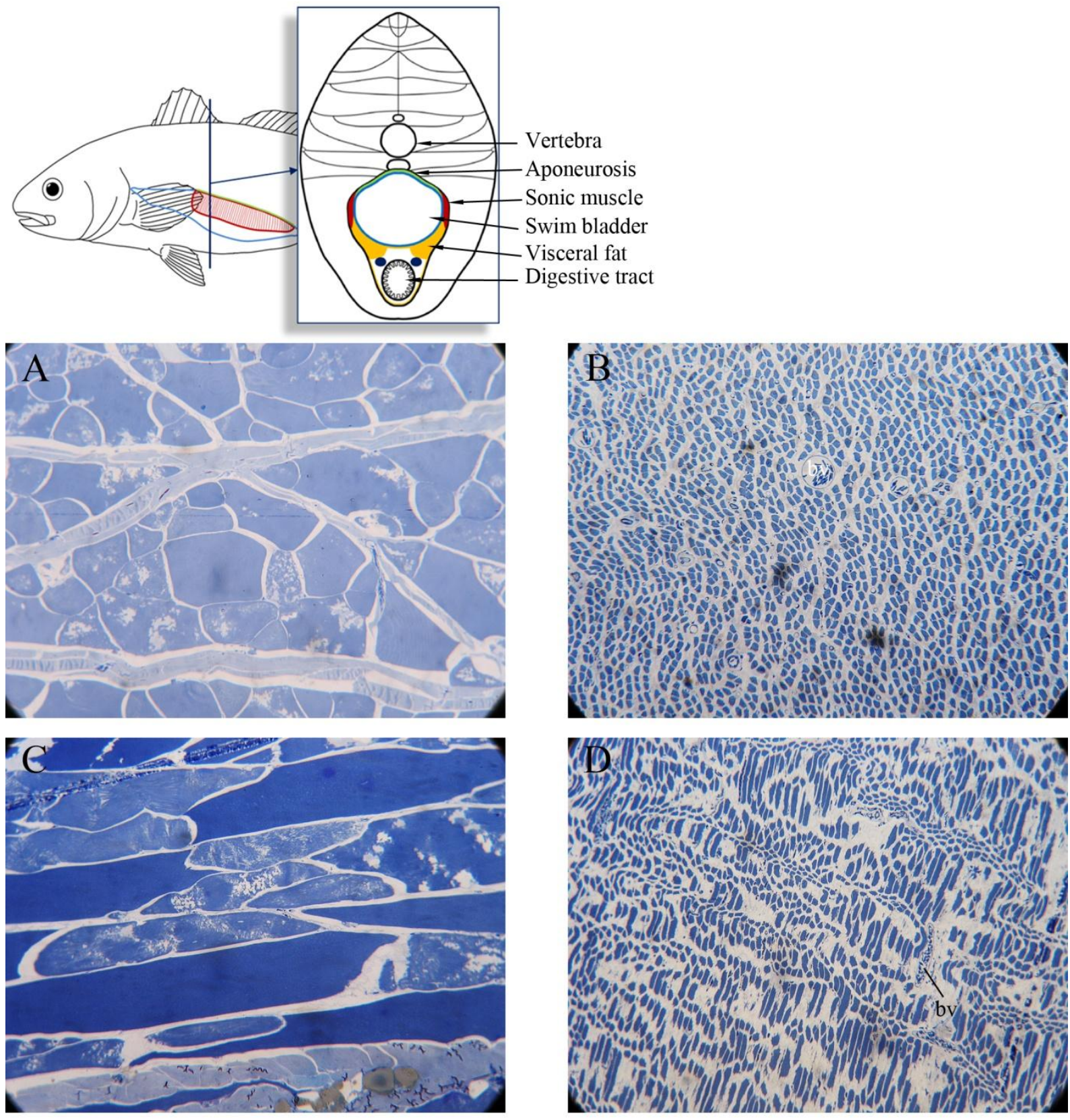

Figure 4 

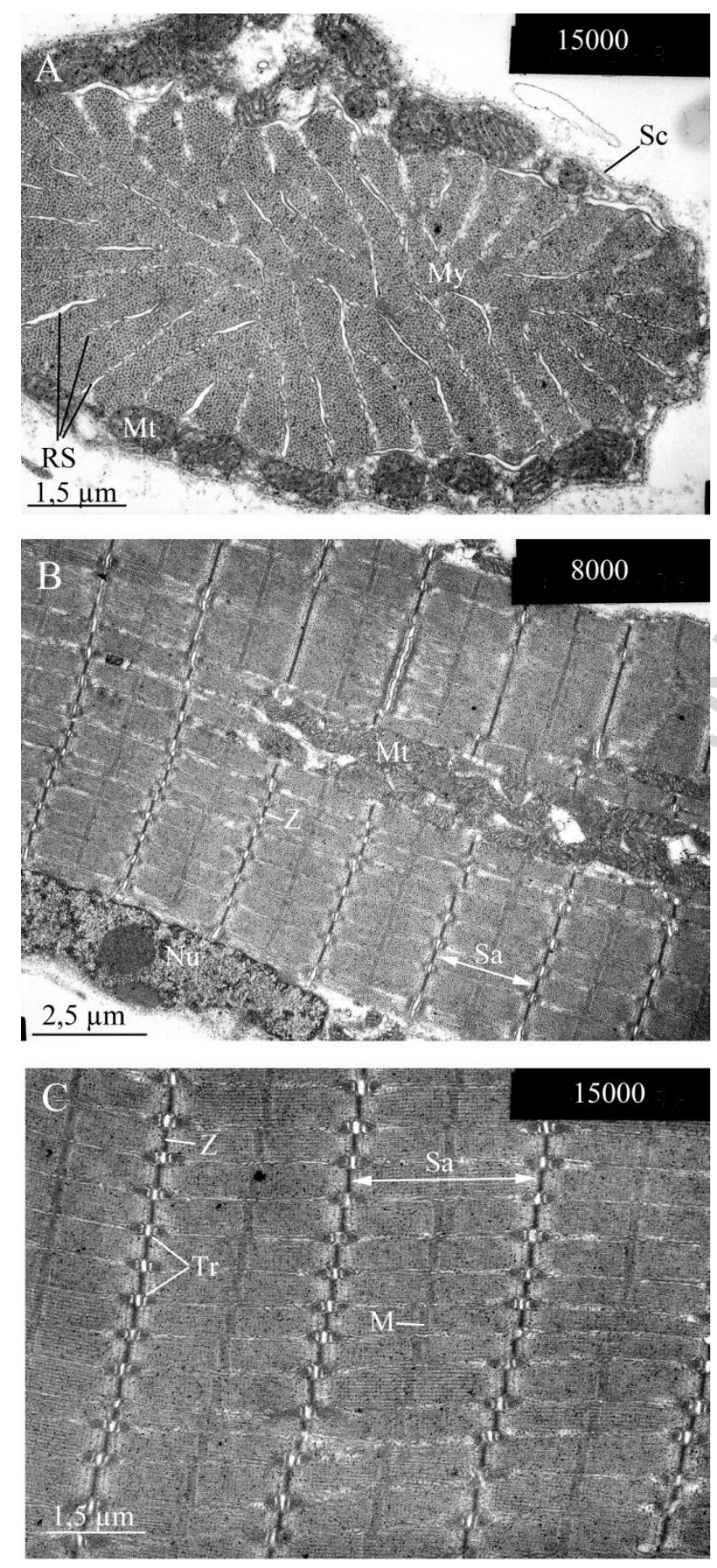

Figure 5 
Table 1. Sciaenops ocellatus sound features, mean \pm SD $(n)$, measured in calls of three pulses that were recorded in different environments.

\begin{tabular}{lcccc}
\hline Floating cage & $\begin{array}{c}\text { Concrete tank } \\
\left(13 \mathrm{~m}^{3}\right)\end{array}$ & $\begin{array}{c}\text { Resine tank } \\
\left(13 \mathrm{~m}^{3}\right)\end{array}$ & $\begin{array}{c}\text { Resine tank } \\
\left(6 \mathrm{~m}^{3}\right)\end{array}$ \\
\hline Fish weight $(\mathrm{kg})$ & $1-7$ & $2,3-6,2$ & $2,1-6,4$ & $3-7,4$ \\
Number of fish & $\begin{array}{c}33 \text { (sex ratio } \\
\text { unknown) }\end{array}$ & $\begin{array}{c}\text { 9 males }-13 \\
\text { females }\end{array}$ & $\begin{array}{c}10 \text { males }-10 \\
\text { females }\end{array}$ & $\begin{array}{c}10 \text { (sex ratio } \\
\text { unknown) }\end{array}$ \\
\hline Sound duration (ms) & $320 \pm 28(100)$ & $343 \pm 31(25)$ & $392 \pm 36(8)$ & $534 \pm 74(11)$ \\
Pulse duration (ms) & $23 \pm 4(100)$ & $24 \pm 2(25)$ & $43 \pm 18(8)$ & $183 \pm 69(11)$ \\
Pulse period (ms) & $144 \pm 12(100)$ & $148 \pm 14(25)$ & $171 \pm 18(8)$ & $169 \pm 10(11)$ \\
Dominant frequency (Hz) & $103 \pm 32(100)$ & $95 \pm 20(25)$ & $500 \pm 237(8)$ & $827 \pm 92(11)$ \\
\hline
\end{tabular}

Table 2. Statistical comparisons (Kruskal Wallis) of the acoustic characteristics of calls recorded in different situations. Mann-Whitney tests were used for paired comparisons. NS: No-significant ; $*=p<0.05 ; * *=p<$ $0.01 ; * * *=\mathrm{p} 0.001$.

\begin{tabular}{lcccc}
\hline & $\begin{array}{c}\text { Sound } \\
\text { duration }\end{array}$ & Pulse duration & Pulse period & $\begin{array}{c}\text { Dominant } \\
\text { frequency }\end{array}$ \\
\hline Kruskal-Wallis & $\begin{array}{c}\mathrm{H}=52.92 \\
\mathrm{p}<0.001\end{array}$ & $\begin{array}{c}\mathrm{H}=50.26 \\
\mathrm{p}<0.001\end{array}$ & $\begin{array}{c}\mathrm{H}=34.38 \\
\mathrm{p}<0.001\end{array}$ & $\begin{array}{c}\mathrm{H}=46.18 \\
\mathrm{p}<0.001\end{array}$ \\
Sea vs Concrete & $*$ & $\mathrm{NS}$ & $\mathrm{NS}$ & $\mathrm{NS}$ \\
Sea vs Resin $\left(13 \mathrm{~m}^{3}\right)$ & $* * *$ & $* * *$ & $* *$ & $* * *$ \\
Sea vs Resin $\left(6 \mathrm{~m}^{3}\right)$ & $* * *$ & $* * *$ & $* * *$ & $* * *$ \\
Concrete vs Resin $\left(13 \mathrm{~m}^{3}\right)$ & $\mathrm{NS}$ & $*$ & $*$ & $* *$ \\
Concrete vs Resin $\left(6 \mathrm{~m}^{3}\right)$ & $* *$ & $* * *$ & $* *$ & $* * *$ \\
Resin $\left(6 \mathrm{~m}^{3}\right)$ vs Resin & $\mathrm{NS}$ & $\mathrm{NS}$ & $\mathrm{NS}$ & $\mathrm{NS}$ \\
$\left(13 \mathrm{~m}^{3}\right)$ & & & & \\
\hline
\end{tabular}

